\title{
Caffeic Acid Phenethyl Ester Menurunkan Ekspresi Endoglin pada Kultur HUVECs yang Dipapar Glukosa Tinggi
}

\section{Caffeic Acid Phenethyl Ester Decrease Endoglin Expression in HUVECs Culture Exposed to High Glucose Concentration}

\author{
Safaruddin Refa, Tri Ayu L \\ Laboratorium IImu Kesehatan Mata Rumah Sakit Umum Dr. Saiful Anwar Malang
}

\begin{abstract}
ABSTRAK
Komplikasi vaskuler pada diabetes mellitus (DM) menimbulkan keadaan hipoksia yang berlanjut pada proses angiogenesis yang dapat dicegah dengan antiioksidan diantaranya caffeic acid phenethyl Ester (CAPE). Penelitian ini bertujuan untuk mengetahui efek pemberian CAPE terhadap ekspresi endoglin pada HUVECs yang dipapar glukosa tinggi. Penelitian ini menggunakan desain analitik eksperimental pada HUVECs primer yang dipapar glukosa tinggi. HUVECs dibagi menjadi 5 kelompok yaitu: 1. HUVECs+DMSO (kontrol negatif), 2. HUVECs+glukosa $22 \mathrm{mM}+\mathrm{DMSO}$ (kontrol positif), 3. HUVECs+glukosa 22 mM+CAPE $3 \mu \mathrm{M}+$ DMSO 4. HUVECs+glukosa $22 \mathrm{mM}+\mathrm{CAPE} 10 \mu \mathrm{M}+\mathrm{DMSO}, 5$. HUVECs+glukosa 22 $\mathrm{mM}+\mathrm{CAPE} 30 \mu \mathrm{M}+\mathrm{DMSO}$. Inkubasi dilakukan selama 48 jam pada suhu $37^{\circ} \mathrm{C}$, lalu dilakukan pengecatan imunositokimia menggunakan antibodi endoglin. Ekspresi endoglin diamati dengan mikroskop cahaya 400x, endoglin tervisualisasi berwarna coklat. Didapatkan perbedaan efek CAPE di antara kelompok perlakuan terhadap ekspresi endoglin pada HUVECs yang dipapar glukosa tinggi (ANOVA $p=0,000$ ). Ekspresi endoglin pada tiap kelompok didapatkan perbedaan signifikan (Tukey test, $p<0,05$ ), kecuali antar kelompok 1 dan 5 tidak didapatkan perbedaan signifikan $($ Tukey test, $p>0,05)$. Dengan Person test didapatkan korelasi positif signifikan antara pemberian CAPE dengan ekspresi endoglin pada HUVECs yang dipapar glukosa tinggi $(r=-0,839 ; p=0,000)$. Pemberian CAPE dapat menurunkan ekspresi endoglin pada HUVECs yang dipapar glukosa tinggi.
\end{abstract}

Kata Kunci: Caffeic acid phenetyl ester, endoglin, HUVECS

\begin{abstract}
Hypoxia is a vascular complication in diabetes mellitus (DM) that lead to angigenesis process which can be prevented using antioxidant such as caffeic acid phenethyl ester (CAPE). This research was aimed to determine the effect of caffeic acid phenethyl ester (CAPE) on endoglin expression in HUVECS culture exposed to high concentration of glucose. The design of this research was an experimental study using high glucose consentration-exposed primary HUVECs. Samples were divided into 5 groups: 1. HUVECS+DMSO (negative control), 2. HUVECS+22mM glucose+DMSO (positive control), 3. HUVECS+22 $m M$ glucose+CAPE $3 \mu M+D M S O, 4$. HUVECs+22 mM glucose+CAPE $10 \mu M+D M S O, 5$. HUVECS+22 mM glucose+CAPE 30 $\mu M+D M S O$. Cultured cells were incubated 48 hours in $37^{\circ} \mathrm{C}$ temperature and endoglin expression were observed with immunocytochemistry method using monoclonal antibody to endoglin. Endoglin expression that visualized with brown colour were examined under microscopic with 400x magnification. There were a difference of endoglin expression among treatment groups (ANOVA $p=0,000$ ). We found significant differences of endoglin expression in each group, however no difference between group 1 and 5. Pearson test show a positive significant correlation between CAPE administration and endoglin expression in high glucose concentration-exposed HUVECs $(r=-0,839 ; p=0,000)$. Increasing dose of CAPE will decrease endoglin expression. Administration of CAPE will decrease endoglin expression in glucose exposed HUVECS.
\end{abstract}

Keywords: Caffeic acid phenetyl ester, endoglin, HUVECs.

Jurnal Kedokteran Brawijaya, Vol. 27, No. 4, Agustus 2013; Korespondensi: Tri Ayu L. Laboratorium Ilmu Kesehatan Mata Rumah Sakit Umum Dr. Saiful Anwar Malang, Jl. Jaksa Agung Suprapto No.2 Malang, Tel. (0341) 341945 Email: dr.ayuwibowo@gmail.com 


\section{PENDAHULUAN}

Diabetes mellitus (DM) merupakan salah satu penyakit metabolik terbanyak di dunia yang mengenai 220 juta jiwa pada tahun 2010 dan diperkirakan menjadi 360 juta jiwa pada tahun 2030. Di Indonesia diperkirakan 12 juta orang akan menderita DM pada tahun 2025 (1,2). Diabetes mellitus yang tidak terkontrol dengan baik akan menyebabkan terjadinya dua komplikasi utama yaitu mikroangiopati (retinopati, nefropati, neuropati) dan makroangiopati (aterosklerosis) (3-5). Retinopati diabetika (RD) merupakan komplikasi yang sering terjadi pada-penderita DM tipe 1 maupun tipe 2 dan merupakan penyebab kebutaan yang tersering pada penduduk usia produktif (20-74 tahun) (2). Prevalensi RD berbeda di tiap negara. Di Indonesia dilaporkan prevalensi RD sebesar $27,2 \%$, dengan angka kejadian kebutaan akibat DM di Indonesia belum diketahui pasti (1). Kebutaan pada DM disebabkan oleh berbagai faktor yang berhubungan dengan RD yang berat (3).

Komplikasi vaskuler pada DM adalah akibat hiperglikemi yang terus-menerus, menyebabkan perubahan homeostasis baru pada sel endotel. Hiperglikemia telah dibuktikan oleh banyak peneliti menyebabkan peningkatan radikal bebas melalui berbagai jalur seperti peningkatan auto-oksidasi glukosa, glikosilasi non enzimatik, perubahan jalur inositol dan mioinositol dan aktivasi jalur diasilgliserol (DAG) serta protein kinase-C (PKC) (4-6). Mekanisme tersebut akan menimbulkan keadaan hipoksia yang berlanjut pada proses angiogenesis (7).

Pada keadaan hipoksia akan muncul hypoxia-inducible factor-1 $\alpha$ (HIF-1 $\alpha$ ) yang merupakan aktivator transkripsi, berfungsi sebagai regulator utama homeostasis oksigen, baik tingkat seluler maupun sistemik (7). Pada tingkat seluler, penurunan tekanan $\mathrm{O}_{2}$ (hipoksia) menyebabkan aktivasi jalur metabolisme alternatif yang tidak membutuhkan molekul oksigen. Ekspresi berbagai macam stres pada protein akan menentukan respon sel hidup atau mati. Adaptasi tingkat jaringan dan sistemik menyebabkan peningkatan transport oksigen ke jaringan. Hal ini termasuk induksi eritropoisis, angiogenesis, dan hiperventilasi (8-11).

Proses angiogenesis akibat peningkatan HIF-1 $\alpha$ terdiri dari beberapa mekanisme yaitu peningkatan faktor pertumbuhan angiogenik, degradasi matriks ekstra sel, migrasi dan proliferasi sel endotel, pembentukan komponen matriks ekstra sel baru dan diikuti pembentukan pipa kapiler baru $(12,13)$. Salah satu faktor pertumbuhan angiogenik yang saat ini banyak diteliti oleh karena keterlibatannya dalam proses neovaskularisasi akibat peningkatan HIF-1 $\alpha$ adalah endoglin (Eng,CD105). Endoglin adalah protein transmembran yang dikenal sebagai penanda terpercaya untuk proliferasi sel endotel dan pembentukan pipa kapiler baru (14). Endoglin diekspresikan berlebih oleh jaringan endotel vaskular yang mengalami angiogenesis, seperti RD, jaringan inflamasi dan tumor (15). Penelitian tentang endoglin menunjukkan keterlibatan endoglin pada proses angiogenesis, perkembangan vaskular dan homeostasis $(16,17)$. Penelitian oleh Sanchez et al secara in vitro menggunakan kultur sel endotel vena umbilikus manusia/ human umbilical vein endothelial cells (HUVECs) didapatkan endoglin meningkat pada keadaan hipoksia terkait meningkatnya komplek HIF-1 (18).
Saat ini telah diteliti berbagai macam antioksidan untuk menghambat atau mencegah angiogenesis, diantaranya adalah caffeic acid phenethyl ester (CAPE) yaitu salah satu komponen terbesar propolis. Propolis (bee glue) merupakan bahan resin berwarna gelap yang dikumpulkan oleh lebah madu Apis mellifera dari kuncup tanaman hidup maupun kulit pohon konifer, yang dicampur dengan lilin lebah (bee wax) dan cairan ludah lebah. CAPE merupakan salah satu komponen yang terkandung dalam propolis memiliki efek sebagai anti oksidan, anti inflamasi, anti viral, anti kanker dan imonomodulator, yang telah diteliti tidak berbahaya bagi sel normal $(19,20)$. CAPE dikenal sebagai antioksidan, dengan mekanisme menghambat produksi reactive oxygen species (ROS) dalam sel. Dari penelitian terbaru tentang CAPE, disinyalir adanya efek anti angiogenesis dari CAPE melalui mekanisme penghambatan ROS $(21,22)$. Izuta et al dalam penelitiannya secara in vitro dengan HUVECs yang dipapar vascular endothelial growth factor (VEGF) pada kejadian retinopati diabetika telah dibuktikan adanya efek CAPE sebagai anti angiogenesis melalui penghambatan ROS dan penghambatan aktivasi nuclear transcription factor kappa $B$ (NF-kB) yang berperan pada proses transkripsi $\operatorname{VEGF}(23)$.

Sampai saat ini belum ada penelitian in vitro maupun in vivo yang menghubungkan CAPE sebagai anti angiogenesis melalui mekanismenya sebagai antioksidan terhadap faktor pertumbuhan angiogenik endoglin. Penelitian laboratoris yang secara langsung memaparkan CAPE pada HUVECs yang dipapar glukosa tinggi akan memberikan gambaran peran CAPE sebagai anti angiogenesis yang ditandai dengan menurunnya kadar endoglin.

\section{METODE}

Sampel sel endotel yang digunakan pada penelitian ini berasal dari umbilikus bayi yang baru lahir dengan kriteria inklusi sebagai berikut: ibu tidak menderita diabetes mellitus maupun hipertensi, riwayat kehamilan normal, tidak anemia, persalinan secara sectio caesaria. Kultur sel endotel (HUVECs) dibuat kurang dari 12 jam setelah pengambilan, kemudian sampel dibagi menjadi 5 grup: 1 . HUVECs, 2. HUVECs+Glukosa, 3. HUVECs+Glukosa+CAPE 3 $\mu \mathrm{M}$, 4. HUVECs+Glukosa+CAPE $10 \mu \mathrm{M}, 5$. HUVECs+ Glukosa+CAPE $30 \mu \mathrm{M}$ semua dengan penambahan DMSO. Glukosa yang digunakan adalah glukosa 22 mM (DGlucose, Sigma Chemical Co. Ltd-USA), paparan dilakukan selama 48 jam. Caffeic acid phenethyl ester (Cayman Chemical Co. Ltd-Michigan,USA) diberikan bersamaan dengan paparan glukosa. Ekspresi endoglin dihitung menggunakan teknik imunositokimia menggunakan antibodi monoklonal anti CD105 (Santa Cruz Co. Ltd-USA). Sel endotel yang mengekspresikan endoglin akan tampak berwarna kecoklatan pada membran selnya. Perbandingan endoglin antar 5 kelompok dilakukan dengan uji ANOVA dilanjutkan dengan uji Tukey dan uji korelasi.

\section{HASIL}

Pengamatan terhadap jumlah ekspresi endoglin pada HUVECs yang dipapar glukosa tinggi dalam beberapa dosis CAPE dan kontrol positif serta kontrol negatif menunjukkan hasil yang sangat bervariasi. Adanya perbedaan dosis CAPE pada setiap kelompok memberikan pengaruh atau efek yang berbeda dalam menurunkan 
jumlah ekspresi endoglin pada kultur sel endotel vaskular yang dipapar glukosa tinggi.

Tabel 1. Rata-rata ekspresi endoglin dalam beberapa variasi dosis CAPE

\begin{tabular}{lc}
\hline \multicolumn{1}{c}{ Perlakuan } & Ekspresi Endoglin (Rerata \pm SD) \\
\hline Kontrol Negatif & $16,4 \pm 2,30$ \\
Kontrol Positif & $47 \pm 7,91$ \\
Glukosa 22 mM+CAPE $3 \mu \mathrm{M}+\mathrm{DMSO}$ & $35,8 \pm 3,96$ \\
Glukosa 22 mM+CAPE 10 $\mu$ M+DMSO & $27,4 \pm 2,30$ \\
Glukosa 22 mM+CAPE 30 $\mu \mathrm{M}+\mathrm{DMSO}$ & $18,8 \pm 2,39$ \\
\hline
\end{tabular}

Adanya pengaruh CAPE tersebut mulai terlihat karena jumlah ekspresi endoglin pada HUVECs yang dipapar glukosa tinggi menjadi lebih menurun setelah diberikan perlakuan berupa CAPE mulai pada dosis $3 \mu \mathrm{M}$ dibandingkan dengan jumlah ekspresi endoglin pada kelompok kontrol positif. Jumlah ekspresi endoglin pada HUVECs yang dipapar glukosa tinggi cenderung semakin menurun ketika diberi dosis CAPE yang lebih tinggi. Bahkan pada dosis yang lebih tinggi yaitu dosis $30 \mu \mathrm{M}$ menunjukkan jumlah ekspresi endoglin pada HUVECs yang dipapar glukosa tinggi hampir mendekati jumlah ekspresi endoglin pada kelompok kontrol negatif. Dengan demikian, berdasarkan penilaian secara deskriptif menurut rata-rata jumlah ekspresi endoglin pada HUVECs yang dipapar glukosa tinggi tersebut, maka dapat dikatakan bahwa perlakuan berupa pemberian CAPE menunjukkan efek atau pengaruh dalam menurunkan jumlah ekspresi endoglin yang berbeda jika dibandingkan dengan ekspresi endoglin pada kontrol positif.

Tabel 2. Uji pembandingan berganda Tukey

\begin{tabular}{llcc}
\hline \multicolumn{2}{c}{ Pembandingan antar Perlakuan } & $\begin{array}{c}\text { Beda } \\
\text { rata-rata }\end{array}$ & $\begin{array}{c}\text { Sig. } \\
\text { (p-value }\end{array}$ \\
\hline \multirow{4}{*}{ Kontrol Positif } & Glukosa22 mM+CAPE 3 uM+DMSO & 11,2 & 0,005 \\
& Glukosa22 mM+CAPE 10uM+DMSO & 19,6 & 0,000 \\
& Glukosa22 mM+CAPE 30uM+DMSO & 28,2 & 0,000 \\
Glukosa22 mM+CAPE3 3 & Glukosa22 mM+CAPE 10uM+DMSO & 8,4 & 0,044 \\
uM+DMSO & Glukosa22 mM+CAPE 30uM+DMSO & 17 & 0,000 \\
Glukosa22mM+CAPE & Kontrol Negatif & 19,4 & 0,000 \\
10 uM+DMSO & Glukosa22 mM+CAPE 30uM+DMSO & 8,6 & 0,038 \\
Glukosa22 mM+CAPE & Kontrol Negatif & 11 & 0,006 \\
30uM+DMSO & Kontrol Negatif & 2,4 & 0,903 \\
\hline
\end{tabular}

Uji Tukey menunjukkan bahwa antara ekspresi endoglin pada kelompok kontrol positif berbeda signifikan (bermakna) dengan ekspresi endoglin pada kelompok perlakuan yang diberi glukosa $22 \mathrm{mM}+\mathrm{CAPE} 3 \mu \mathrm{M}+\mathrm{DMSO}$, glukosa $22 \mathrm{mM}+\mathrm{CAPE} 10 \mu \mathrm{M}+\mathrm{DMSO}$, glukosa 22 mM+CAPE $30 \mu \mathrm{M}+\mathrm{DMSO}$ dan kontrol negatif $(p<0,05)$. Ekspresi endoglin pada kelompok perlakuan yang diberi glukosa 22 mM+CAPE $30 \mu \mathrm{M}+\mathrm{DMSO}$ tidak berbeda signifikan (tidak bermakna) dengan ekspresi endoglin pada kelompok kontrol negatif $(p=0,903)$. Uji korelasi menunjukkan korelasi negatif yang kuat dan signifikan ( $r=-$ $0,839, p=0,000)$.
Model regresi dari pengaruh CAPE dengan ekspresi endoglin pada HUVECs yang dipapar glukosa tinggi yaitu $Y=40,928-0,807 X$, dengan $Y$ adalah ekspresi endoglin pada HUVECs yang dipapar glukosa tinggi, sedangkan $X$ adalah pemberian dosis CAPE. Model ini menunjukkan bahwa tanpa dipengaruhi oleh pemberian CAPE, maka ekspresi endoglin pada HUVECs yang dipapar glukosa tinggi akan cenderung meningkat secara konstan 40,928 sel. Akibat pengaruh dari pemberian dosis CAPE, maka setiap peningkatan dosis CAPE $1 \mu \mathrm{M}$ akan menyebabkan ekspresi endoglin mengalami penurunan hingga 0,807 sel. Berdasarkan hasil uji regresi juga menunjukkan nilai koefisien determinasi $70,4 \%$.

\section{DISKUSI}

Endoglin merupakan protein transmembran yang saat ini banyak diteliti karena keterlibatannya pada proses neovaskularisasi. Endoglin dikenal sebagai penanda terpercaya untuk proliferasi sel endotel dan pembentukan pipa pembuluh darah baru (14). Endoglin diekspresikan oleh sel endotel vaskular imatur dan matur, dan diekspresikan berlebih oleh jaringan endotel vaskular yang mengalami angiogenesis (neovaskularisasi), seperti pada retinopati diabetika, jaringan inflamasi dan tumor $(15,24)$. Endoglin dianggap sebagai marker paling cocok untuk menentukan adanya proses angiogenesis $(11,15,16,25)$. Pada penelitian secara in vitro didapatkan endoglin dengan level tertinggi pada sel yang menunjukkan tingkat DNA, RNA dan protein pada saat proliferasi dan aktivasi sel $(14,24)$.

Pada penelitian ini, didapatkan ekspresi endoglin yang lebih tinggi pada kontrol positif $(47 \pm 7,91)$ dibandingkan pada kontrol negatif $(16,4 \pm 2,30)$. Adanya perbedaan ekspresi endoglin tersebut dikarenakan pada HUVECs yang dipapar glukosa tinggi menyebabkan keadaan hiperglikemia pada sel endotel sehingga menimbulkan terbentuknya radikal bebas seperti anion superoksida $\left(\mathrm{O}_{2}\right)$, radikal hidroksil $\left(\mathrm{OH}^{-}\right)$, hidrogen peroksida $\left(\mathrm{H}_{2} \mathrm{O}_{2}\right)$ maupun ketoaldehida melalui otoksidasi glukosa, glikasi protein, peningkatan jalur poliol dan DAG-PKC. Akibat proses ini akan terjadi kerusakan struktural sel, aktivasi dari NF-B, peningkatkan sitokin, peningkatkan ROS, aktivasi jalur PKC, penurunan kadar GSH yang menimbulkan disfungsi sel endotel dan dapat menyebabkan keadaan hipoksia pada sel sehingga timbul kerusakan biomolekul yang penting seperti DNA, protein dan lipid $(7,26,27)$. Pada keadaan hipoksia yang ditandai dengan adanya HIF-1 $\alpha$ yaitu suatu aktivator transkripsi yang mempunyai fungsi sebagai regulator utama homeostasis oksigen, baik tingkat seluler maupun sistemik, dapat mensekresi faktor-faktor angiogenesis. Salah satu protein yang dipercaya sebagai faktor angiogenesis terkait hipoksia adalah endoglin. Hal ini didukung oleh penelitian oleh Li et al secara in vitro didapatkan hasil bahwa keadaan hipoksia meningkatkan ekspresi dari protein endoglin (11). Dari penelitian oleh Sanchez et al secara in vitro telah diketahui bahwa ekspresi endoglin meningkat terkait dengan adanya TGF- $\beta$ maupun keadaan hipoksia yang ditandai dengan adanya HIF-1 $\alpha$. Kondisi hipoksia ini dapat meningkatkan ekspresi endoglin satu setengah kali sampai dua kali $(7,11,18)$.

Untuk menurunkan ekspresi dari protein angiogenesis (endoglin) dapat dilakukan dengan pemberian antioksidan. Antioksidan adalah molekul-molekul yang menangkap radikal bebas dan memblok rantai reaksi dari 
oksidasi yang tidak teregulasi sebelum kerusakan terjadi. Antioksidan ini merupakan senyawa pemberi elektron (donor elektron) yang dapat meredam dampak negatif dari oksidan. Beberapa sistem enzim dalam tubuh dapat melakukan scavenger radikal bebas, seperti SOD, katalase maupun GSH. Antioksidan mikronutrien biasanya didapat dari asupan makanan, diantaranya yang saat ini sedang banyak diteliti adalah CAPE yang merupakan salah satu kandungan dari propolis yang memiliki efek antioksidan yang lebih tinggi dibandingkan produk lebah lainnya seperti royal jelly dan bee pollen, maupun antioksidan lainnya yaitu vitamin C dan $\mathrm{E}(19,22,23)$.

Pada penelitian ini didapatkan hasil bahwa antara pemberian CAPE dengan penurunan ekspresi endoglin pada HUVECs yang dipapar glukosa tinggi mempunyai hubungan yang signifikan dengan arah korelasi yang negatif. Korelasi negatif mempunyai arti peningkatan dosis CAPE cenderung akan menurunkan ekspresi endoglin pada HUVECs yang dipapar glukosa tinggi, dibandingkan dengan ekspresi endoglin pada dosis CAPE yang lebih rendah. Dari hasil uji regresi disimpulkan bahwa pemberian dosis CAPE sangat berpengaruh terhadap penurunan ekspresi endoglin pada HUVECs yang dipapar glukosa tinggi sebesar $70,4 \%$, dan $29,6 \%$ keragaman ekspresi endoglin pada HUVECs yang dipapar glukosa tinggi dipengaruhi oleh faktor lain selain pemberian CAPE, diantaranya antioksidan intraselular. Semakin tinggi dosis CAPE yang dipergunakan, maka akan berpengaruh signifikan dalam menurunkan ekspresi endoglin pada HUVECs yang dipapar glukosa tinggi.

Hal tersebut diatas diperkuat oleh penelitian Izuta et al yang menunjukkan CAPE memiliki efek antioksidan yang lebih tinggi dibanding produk lebah lainnya serta memiliki aktifitas angiostatik yang lebih baik (23). Semakin tinggi dosis CAPE akan dapat menurunkan faktor angiogenesis semakin besar. Penelitian oleh Mustafa et al dengan menggunakan model tikus diabetik yang diberi streptozocin (STZ) juga mendukung efek positif dari pemberian CAPE, dimana dalam penelitian ini didapatkan hasil bahwa pemberian CAPE dapat menurunkan kadar malondialdehide (MDA), nitric oxide (NO) dan meningkatkan aktivitas enzim superoxide dismutase (SOD) (28). CAPE juga diketahui dapat menurunkan secara signifikan jalur lipooksigenase dari metabolisme asam arakhidonat pada saat terjadinya inflamasi (22). CAPE telah diteliti memiliki efek biologis maupun farmakologis dan tidak berbahaya bagi sel normal. Efek dari CAPE

\section{DAFTAR PUSTAKA}

1. Perkumpulan Endokrinologi Indonesia. Konsensus Pengelolaan Diabetes Mellitus Tipe 2 di Indonesia. Jakarta: PERKENI; 2003.

2. Apushkin M, Scott L, and Lyon A. Screening for Spesific Disease. Clinical Pathways in Vitreoretina Disease. New York: Thieme Medical Publishers Inc.; 2003: p. 374-377.

3. DaSilva Z, Freitas AM, and Marcon IM. Risk Factors Related to Severity of Diabetic Retinopathy. Arquivos Brasileiros de Oftalmologia. 2003; 66: 739-743.

4. Stehouwer CD, Lambert J, Donker AJ, and Van Hinsbergh VW. Endothelial Dysfunction and Pathogenesis of Diabetic Angiopathy. Cardiovascular antara lain sebagai antioksidan, anti-inflamasi, antiviral, antikanker dan sebagai imonomodulator. CAPE saat ini dikenal sebagai antioksidan, dan diketahui memiliki efek yang lebih kuat dibandingkan alpha tocopherol (vitamin E) maupun ascorbic acid (vitamin C). Mekanisme CAPE sebagai antioksidan adalah dengan menghambat produksi $\operatorname{ROS}(23)$

Hasil uji One Way ANOVA menunjukkan bahwa terdapat perbedaan efek CAPE pada setiap perlakuan terhadap ekspresi endoglin pada HUVECs yang dipapar glukosa tinggi. Pada penelitian ini juga diketahui adanya perbedaan signifikan dari penurunan ekspresi endoglin pada HUVECs yang dipapar glukosa tinggi pada kelompok kontrol positif dibanding pada kelompok kontrol negatif dan kelompok yang mendapatkan CAPE dalam berbagai dosis ( $3 \mu \mathrm{M}, 10 \mu \mathrm{M}$ dan $30 \mu \mathrm{M})$. Beda rata-rata penurunan terbesar adalah pada kelompok yang mendapatkan CAPE dosis $30 \mu \mathrm{M}$ (beda rata-rata=28,2, $p=0,000$ ). Antara kelompok yang mendapatkan CAPE $30 \mu \mathrm{M}$ dengan kontrol negatif tidak didapatkan perbedaan signifikan dari ekspresi endoglin. Hal ini dikarenakan CAPE dosis $30 \mu \mathrm{M}$ sudah mendekati dosis CAPE yang diperlukan agar ekspresi endoglin mendekati normal (kontrol negatif). Hal ini sesuai perhitungan berdasarkan uji regresi dosis CAPE yang diperlukan agar ekspresi endoglin mendekati normal tersebut adalah 30,394 $\mu \mathrm{M}$.

Pemilihan dosis pada penelitian ini didasarkan pada beberapa penelitian in vitro terdahulu, diketahui bahwa penggunaan CAPE dengan konsentrasi mulai dari 1-10 $\mu \mathrm{M}$ cukup mendapatkan CAPE yang diabsorbsi oleh sel $(23,29)$. Penelitian oleh Sud'ina GF et al menunjukkan bahwa dengan pemberian CAPE dosis $10 \mu \mathrm{M}$ didapatkan penurunan dari ROS pada neutrofil manusia yang mengalami oksidasi (29). Penelitian oleh Izuta et al, telah membuktikan adanya efek CAPE dengan dosis 1-12,8 $\mu \mathrm{M}$ yang diberikan pada HUVECs yang dipapar VEGF. Diketahui adanya CAPE sebagai anti angiogenesis dan antioksidan yang kuat dibandingkan produk madu dan komponen propolis lainnya (23). Pada penelitian tersebut didapatkan dosis paling efektif CAPE sebagai antioksidan adalah 12,8 $\mu \mathrm{M}(3,6 \mu \mathrm{g} / \mathrm{ml})$, dan efek CAPE sebagai angiostatik sudah terlihat pada pemberian CAPE dosis $1 \mu \mathrm{M}(0,3 \mu \mathrm{g} / \mathrm{ml})(23)$. Penelitian ini membuktikan efek CAPE sebagai anti angiogenesis yang ditunjukkan dengan penurunan ekspresi faktor pertumbuhan angiogenik endoglin.

Research. 1997; 34(1): 55-68.

5. Cai J and Boulton M. The Pathogenesis of Diabetic Retinopathy: Old Concepts and New Questions. Eye. 2002; 16 : 242-260.

6. Cines DB, Pollak ES, Buck CA, et al. Endothelial Cells in Physiology and in the Pathophysiology of Vascular Disorders. Blood. 1998; 91: 3527-3561.

7. Catrina S, Okamoto K, Pereira T, Brismar K, and Poellinger L. Hyperglycemia Regulates HypoxiaInducible Factor 1- $\alpha$ Protein Stability and Function. Diabetes. 2004; 53(12): 3226-3232.

8. Michiels C, Arnould T, and Remacle J. Endothelial Cell Responses to Hypoxia: Initiation of Cascade of Cellular Interactions. Biochimica et Biophysica Acta. 2000; 
1497(1): 1-10.

9. Orević G, Matušan-Ilijaš K, Babarović E, et al. Hypoxia Inducible Factor-1a Correlates with Vascular Endothelial Growth Factor A and C Indicating Worse Prognosis in Clear Cell Renal Cell Carcinoma. Journal of Experimental and Clinical Cancer Research. 2009; 28: 40.

10. Tailor A and Granger D. Role of Adhesion Molecules in Vascular Regulation and Damage. Current Hypertension Reports. 2000; 2: 78-83.

11. Li C, Issa R, Kumar P, et al. CD105 Prevents Apoptosis in Hypoxic Endothelial Cells. Journal of Cell Science. 2003; 116: 2677-2685.

12. Felmeden D, Blann A, and Lip G. Angiogenesis: Basic Pathophysiology and Implication for Disease. European Heart Journal. 2003; 24: 586-603.

13. Pepper M. Manipulating Angiogenesis from Basic Science to Bedside. Atherosclerosis, Thrombosis, and Vascular Biology. 1997; 17: 605-619.

14. Fonsatti E, Nicolay HJM, Altomonte M, Covre A, and Maio M. Targeting Cancer Vasculature Via Endoglin/CD105: A Novel Antibody-Based Diagnostic and Therapeutic Strategy in Solid Tumours. Cardiovascular Research. 2010; 86: 12-19.

15. Wikstrom P, Lissbrant I, Stattin P, Egevad L, and Bergh A. Endoglin (CD105) is Expressed on Immature Blood Vessels and is a Marker for Survival in Prostate Cancer. The Prostate. 2002; 51: 268-275.

16. Wong S, Hamel L, Chevalier S, and Philip A. Endoglin Expression on Human Microvascular Endothelial Cells Association with Betaglycan and Formation of Higher Order Complexes with TGF-beta Signalling Receptors. European Journal of Biochemistry. 2000; 267: 55505560.

17. Ten Dijke P, Goumans M, and Pardali E. Endoglin in Angiogenesis and Vascular Diseases. Angiogenesis. 2008; 11: 79-89.

18. Sanchez-Elsner T, Botella LM, Velasco B, Langa C, and Bernabeu C. Endoglin Expression is Regulated by Transcriptional Cooperation Between Hypoxia and Transforming Growth Factor-b Pathways. Journal of Biological Chemistry. 2002; 277: 43799-43808.

19. Cicala C, Morello S, lorio C, Capasso R, Borrelli F, and Mascolo N. Vascular Effects of Caffeic Acid Phenethyl Ester (CAPE) on Isolated Rat Thoracic Aorta. Life Sciences. 2003; 73: 73-80.
20. Natarajan K, Singh S, Burke T, Grunberger D, and Aggarwal B. Caffeic Acid Phenethyl Ester is a Potent Specific Inhibitor of Activation of Nuclear Transcription Factor NF-kB. Immunology. 1996; 93: 9090-9095.

21. Ushio-Fukai M, Tang Y, Fukai T, et al. Novel Role of gp91 (phox)-containing NAD $(P) H$ Oxidase in Vascular Endothelial Growth Factor-Induced Signaling and Angiogenesis. Circulation Research. 2002; 91(12): 1160-1167.

22. Durmuş M, Yilmaz HR, Uz E, and Özçelik N. The Effect of Caffeic Acid Phenethyl Ester (CAPE) Treatment on Levels of MDA, NO and Antioxidant Enzyme Activities in Retinas of Streptozotocin-Induced Diabetic Rats. Turkish Journal of Medical Sciences. 2008; 38(6): 525530.

23. Izuta H, Simizawa M, Tsuruma K, Araki Y, Mishima S, and Hara H. Bee Products Prevent VEGF-Induced Angiogenesis in Human Umbilical Vein Endothelial Cells. Biomed Complementary and Alternative Medicine. 2009; 9: 45.

24. Torsney B, Charlton R, Parums D, Collin M, and Arthur $\mathrm{H}$. Inducible Expression of Human Endoglin During Inflammation and Wound Healing. Inflammation Research. 2002; 51(9): 464-470.

25. Schalkwijk CG and Stehouwer CDA. Vascular Complications in Diabetes Mellitus: the Role of Endothelial Dysfunction. Clinical Science. 2005; 109: 143-159.

26. Treins C, Giorgetti-Peraldi S, Murdaca J, and Van Obberghen E. Regulation of Vascular Endothelial Growth Factor Expression by Advanced Glycation End Products. The Journal of Biological Chemistry. 2001; 276: 43836-43841.

27. Kian AYS and Mustafa S. Influence of Enriched Live Prey and Other Artificial Diets on RNA and DNA Concentration in the Ovary of Tiger Prawn, Penaeus monodon. Journal of Applied Aquaculture. 2005; 16: 147-153.

28. Sud'ina G, Mirzoeva O, Pushkareva G, et al. Caffeic Acid Phenethyl Ester as a Lipoxygenase Inhibitor with Antioxidant Properties. Federation of the Societies of Biochemistry and Molecular Biology Letters. 1993; 329: 21-24.

29. Iraz M, Fadıllığlu E, Taşdemir S, Ateş B, and Erdoğan S. Dose Dependent Effects of Caffeic Acid Phenethyl Ester on Heart Rate and Blood Pressure in Rats. European Journal of General Medicine. 2005; 2(2):69-75 